\title{
New Labour's Ethical Dimension: Statistical Trends in Tony Blair's Foreign Policy Speeches
}

\author{
Densua Mumford and Torsten J. Selck
}

Debate has raged over the extent to which New Labour has succeeded in incorporating an ethical dimension in British foreign policy. The assumption has been that New Labour at least changed the context of foreign policy by adopting a more moralistic language. However, there has been no attempt as yet to show this statistically. Using computer-assisted content analysis of Margaret Thatcher's, Robin Cook's and Tony Blair's foreign policy speeches, and assuming that Blair, as opposed to Cook, is the representative voice of New Labour, this research finds that New Labour has indeed changed the context significantly. However, this change did not occur until after the events of $9 / 11$.

Keywords: New Labour; foreign policy; content analysis; Tony Blair

\section{Introduction}

Language has increasingly come to be considered a useful indicator of a given political context (Fierke 2001, 132). Besides actors' behaviour, their words reveal a lot about them. After taking power in 1997, the New Labour government promised an ethically minded arms industry, claimed to fight in Kosovo on humanitarian grounds, focused upon the environment through the Third Way and promoted internationalism as the way forward in a globalised world (Buller and Harrison 2000, 77; Wickham-Jones 2000a, 11-16; Vickers 2000, 36-37). While some political scientists, in particular Nicholas J. Wheeler and Tim Dunne (1998 and 2004; Dunne and Wheeler 2001) and Jim Buller and Vicky Harrison (2000, 79; see also Hill 2005, 385-386), accept New Labour's rhetoric as a sign of a marked shift in the context of foreign policy discourse, they provide no measurable evidence of this progress. Such a measure would be useful not just to gauge with more precision how much the New Labour government shifted the context of foreign policy, but also to provide a starting point for measuring the general trends regarding ethics in foreign policy.

Using computer-assisted content analysis, this study aims to clarify the differences in moral rhetoric between Margaret Thatcher's Conservative government and Tony Blair's New Labour government. This will highlight the ethical orientation of each party's foreign policy agenda and thus help to clarify the extent to which there can be talk of an emerging ethical dimension. 
We chose Margaret Thatcher over John Major as a case study because she makes the stronger case for representing the Conservative foreign policy agenda. It is Thatcher who, among other achievements, truly defined the Conservative party's foreign policy and Britain's place in the world in the post-cold war era (Seldon and Snowdon 2004, 118; Campbell 2009, 255-257, 502). In comparison, John Major failed to develop his own ideological platform during his years in power, and is credited with merely continuing and concluding the Thatcherite agenda (Hennessy 2001, 443-444; Seldon and Snowdon 2004, 121 ; Marr 2008, 484).

The following question will be central: has New Labour shifted the rhetorical context of foreign policy by incorporating an ethical dimension, and to what extent?

Section 2 will establish in more detail the political and theoretical context in which this study is situated and outline how it will add to existing debate. Following that, Section 3 will clarify the research design and research process, while Section 4 will present the results and answer the hypotheses. Finally, Section 5 will bring together the arguments developed throughout and make suggestions for further research.

\section{Theory}

This section will highlight the relevance of this study by describing the political and theoretical contexts in which it is embedded. The following is thus a brief summary of the current understanding of Margaret Thatcher's, Tony Blair's and Robin Cook's respective positions on foreign policy. It will also show how the research aims to add to existing theoretical understandings of the position of morality in the New Labour agenda. Lastly, it will establish the hypotheses that the study attempts to address.

The Conservative government under Thatcher is traditionally understood as being concerned first and foremost with British national interest in foreign policy. Describing Thatcher's approach to the anti-apartheid movement in South Africa, biographer John Campbell (2003, 318-323; see also Riddell 1991, 196-198) states that she considered what was practical and in the British interest. The Commonwealth leaders, anti-apartheid activists and the British population wanted a change of regime; they thought that penalising South Africa with economic sanctions would lead to a change from minority white rule to majority black rule. Thatcher, however, asserted that the right course was to engage with South Africa rather than to punish it. As the fourth biggest trading partner and a source of minerals, South Africa represented a sizeable object of British business interests. To impose sanctions and wound its economy would have damaged the British defence industry and would have led to the loss of British jobs. Moreover, 800,000 white South Africans were legally entitled to migrate to Britain if their lives were endangered during a change of regime; the implications for the British economy would be highly undesirable. Percy Cradock, one of her leading policy advisers, sums up British foreign policy under Thatcher:

There were ideals, the defence of Western ways of government and Western economic systems; a wish to ensure their spread if possible; a respect for international law, a commitment to international stability. 
These were seen as synonymous with the pursuit of British interests, and it was usually in terms of British interests, narrowly defined, that the governing analysis was made. In such papers there was more about British interests than common international interests (Cradock 1997, 30).

All of this was supposed to change with the arrival of the New Labour government in 1997 (Bogdanor 2005, 448-449). The foreign secretary of the 1997-2001 New Labour government, Robin Cook, is credited with being the spearhead of New Labour's moral approach to foreign policy (The Guardian, 9 April 2001). This was another means for New Labour to distinguish itself from the previous Conservative government. However, it could also be viewed as Cook taking the opportunity to carve a distinctive role for himself in a position that was 'politically unrewarding' (Wickham-Jones 2000b, 107-108; Kampfner 1999, 135). In particular, he is linked to more stringent arms control to ensure that British arms companies would no longer be linked to oppressive regimes (Wickham-Jones 2000a, 11). The British arms industry, according to Cook, was to be as ethical as possible. However, what began as a confident campaign brought about weak results, leading many to criticise the policy as inconsistent and ineffective (Wickham-Jones 2000a, 25). Even Cook was not prepared for the furore his career-boosting exercise generated, and continued media criticism revealed that the public's interpretation of his 'ethical dimension' might have been more extreme than he wished (Little 2000, 254). He later distanced himself from the term 'ethical dimension' (Kampfner 1999, 134; Wickham-Jones 2000a, 4).

The New Labour leader, Tony Blair, on the other hand, became drawn to foreign policy during his premiership. His strong improvisational skills suited the highly unpredictable nature of foreign policy; in turn, foreign policy afforded him the scope to make a difference without facing as nuanced a scrutiny as in domestic policy. He was determined to make his unique mark and to embody the continuity of foreign policy. This was evident in his 2001 reshuffle, when Cook was replaced by Jack Straw (Hill 2005, 385). Furthermore, in drafting a new set of rules to regulate the British arms industry shortly after coming to power, Cook's intended programme was to include strict monitoring, registration and measures to prevent British companies from procuring, manufacturing or selling instruments of torture (Kampfner 1999, 142). However, Blair appeared to be more concerned with the interests of the arms companies than with moral considerations. This is not surprising considering their contribution towards British wealth: 'In 1997 Britain accounted for almost a quarter of the global arms export market, second only to the United States, with sales abroad valued at over £5 billion a year' (Kampfner 1999, 142). During the drafting process, Blair watered down the wording, turning strict mechanistic rules into broad guidelines (Kampfner 1999, 145).

This highlights a tension between Blair's and Cook's priorities (see Wickham-Jones 2000a, 17-23; Vickers 2000, 38-40). While Cook had a strong moral agenda, Blair's concerns were circumscribed by the interests of the British economy just as Thatcher's had been. Tom Porteous $(2005,295)$ provides an example of Blair's priorities: 'On the one occasion when the prime minister was asked unambiguously to choose between what is good for poor Africans and what is good for British industry, he chose the latter'. 
On the other hand, Blair and Cook shared a justification whenever speaking of ethics. For both, globalisation presented the force behind a new respect for human rights and internationalism. In his speech to the Chicago Economic Club in 1999 (www.number-10.gov.uk/), Blair claimed that 'globalisation has transformed our economies and our working practices'. Furthermore, in today's world 'we are all internationalists now, whether we like it or not. We cannot refuse to participate in global markets if we want to prosper. ... We cannot turn our backs on conflicts and the violation of human rights within other countries if we want still to be secure'. His words echo some of the most important globalist theories to date.

Proponents of globalisation theory argue that the international economy is interconnecting at an unprecedented rate, with multinational corporations accounting for 25 per cent of world production and 70 per cent of world trade. As a result national governments have lost much of their control over these processes (Held and McGrew 2002, 48-56; see also Perraton et al. 2000). According to Owen Greene $(2005,452)$, the environment has become an international ethical issue because problems like that of chlorofluorocarbons destroying the ozone layer are inherently global. Other problems such as the pollution of the oceans relate to globally shared resources. The causes of environmental problems 'are closely related to the generation and distribution of wealth, knowledge, and power, and to patterns of energy consumption, industrialization, population growth, affluence, and poverty'. As such, globalisation has inherently moral connotations.

Moreover, if nations are interconnected and affect each other's environments, the notion of responsibility for and duty towards others can be broadened out to incorporate those beyond state borders (see Beitz 1975 and 1999, 516-518). In reality, the harmony implied in this approach-all peoples everywhere converging to become one-is missing. Globalisation, in fact, has led to animosity and interstate conflicts, and has triggered 'reactionary politics' and xenophobia (Held and McGrew 2002, 1). Additionally, it has negative implications for the effectiveness of state sovereignty and state power (Strange 2000, 148-150; Held and McGrew 2002, 16-24) and leads to the erosion of national cultures (Robins 2000, 198; UNDP 2000, 345). Yet for Blair and Cook, the emphasis upon internationalism is not just for functional reasons, but because it is the right choice - the good choice.

Wheeler and Dunne are prominent authors in this field. For them, New Labour rhetoric represents the basis for the development of an ethical foreign policy:

A significant departure from the foreign policy pursued by the previous government concerns the language used by Robin Cook and Tony Blair in key foreign policy speeches. As Mervyn Frost notes, the mission statement is almost wholly unrecognizable when looked at through traditional realist-cum-pragmatist lenses. There is no talk of sovereignty, of which we heard so much from the previous administration, no mention of 'threats' to national security, no elevation of the principle of non-intervention in Britain's domestic affairs; in their place one finds 'internationalism', 'promoting democracy', 'promotion of our values and confidence in our identity', 'a people's diplomacy' and so on (Wheeler and Dunne 1998, 850-851). 
In the conclusion of a more recent article, they claim: 'What is new about the Labour government's foreign policy, and what represents more than a slight resetting of the compass, is that, unlike previous governments, it has created the context for the development of this human rights culture' (Dunne and Wheeler 2001, 184). According to Wheeler and Dunne, New Labour broadened the context of foreign policy to include ethics in a significant way. They present the concept of a 'Good International Citizen' (GIC) who sacrifices political and economic interests in order to protect and promote human rights (Wheeler and Dunne 1998, 868-869).

Several authors share Wheeler and Dunne's key premise of New Labour using a new moral language (for other examples, see Buller and Harrison 2000, 87; Abrahamsen and Williams 2001, 250-251; Dixon and Williams 2001, 153; Bogdanor 2005, 446-448; Hill 2005, 385-386). They do, however, also share some common weaknesses which the study at hand aims to overcome.

Will Bartlett (2000) investigates New Labour's approach to the Kosovo crisis, claiming that the war was spun as an ethical one when the ethical dimension was far from evident in policy. He points to Blair's justifications for the subsequent war against the Federal Republic of Yugoslavia, showing that there were, in fact, several reasons for the conflict. Blair claimed that diplomacy with the Serb government had broken down when, in actuality, a less draconian approach than New Labour's would have made agreement more likely. He claimed that the strikes upon Yugoslavia were legally justified and would bring about morally desirable outcomes when, in fact, the outcomes were far from good and British actions technically counted as aggression under international law (Bartlett 2000, 137-138). Only later, as the campaign became harder to sell as the right course, did morality become the key justification. The supposedly humanitarian conflict required attacks against civilian infrastructures, which went against the moral grain and created obvious tensions between intention and outcome. At the end of the war, morality was put aside once more and the policy to isolate Serbia for strategic reasons became more important than providing aid for the Serbs still being ethnically cleansed (Bartlett 2000, 138-144). According to Bartlett, ethics became a (hypocritical) justification for political actions. But is his assumption of a shift in political discourse justified?

Bartlett's analysis inherently accepts that New Labour discourse was to such an extent morally orientated that the moral elements warrant critique. However, as a case study, his analysis is limited to this particular event and does not provide insight into New Labour's foreign policy discourse as a whole. Nor does Bartlett thoroughly qualify his assumptions of a moral discourse. He concludes that deciding whether the policy towards Kosovo was ethical is not straightforward, but that the government 'did make a large number of statements indicating that this was how it should be seen and how they themselves viewed it' (Bartlett 2000, 143). A 'large number' does not constitute a testable qualification. Moreover, Bartlett reveals New Labour's emphasis upon morality by highlighting both Blair's and Cook's statements interchangeably; it has been noted, however, that their views on foreign policy were not always synchronised (Kampfner 1999, 137, 142; Wickham-Jones 2000a, 5). Finally, Bartlett's analysis is fixated upon the role of morality as if that were the sole consideration in discourse. To be able to extrapolate upon New Labour's foreign policy and the role of ethics within it, a broader, more generalised 
approach needs to be applied, taking into account the relative importance of other variables.

Other critiques of Wheeler and Dunne's (1998) position reveal further problems. Neil Cooper (2000), who explicitly assesses the New Labour rhetoric, focuses on the arms sales issue. He analyses not just formal speeches but also the wording of policy documents. He finds that the change in rhetoric has not marked a negligible shift in the wording of policy documents and a distinct poverty of change in policy behaviour. However, in assessing the speeches, he sidelines Blair's position on the issue. As with Bartlett's (2000) interchangeable use of Cook's and Blair's statements, the neglect of the prime minister's rhetoric might muddy the waters in terms of understanding the supposed ethical shift in discourse.

Lastly, Davina Miller's (2000) assessment of Britain's engagement with Iran also begins with the acceptance of a new moral agenda in foreign policy. She also cites Cook's statements and speeches (Miller 2000, 186-187), assesses New Labour's policy towards Iran and concludes that the New Labour government 'sacrificed human rights considerations' in what looks like a hypocritical foreign policy approach (Miller 2000, 198). Nonetheless, unlike other critics, she recognises the role of national interest in foreign policy. She states that New Labour largely maintained the order of priorities set by the preceding Conservative governments: specifically in regard to Iran, ensuring that more trade and engagement rather than human rights became the norm (Miller 2000, 197). National interest is thus an important variable representing the main counter-consideration to ethics. As Richard Little $(2000,253)$ argues, "the emphasis on the "ethical dimension" has tended to overshadow other aspects of New Labour's foreign policy associated with defence that must presumably also form part of the Third Way'.

In addressing the above weaknesses and advancing the debate, this study aims to apply a new methodology which takes a broad and generalised view of New Labour foreign policy discourse in order to complement the rich, in-depth material already in existence. Moreover, this study takes an empirical approach in order to answer one of the key questions dogging Wheeler and Dunne's (1998 and 2004; Dunne and Wheeler 2001) analysis: to what extent has New Labour reset the compass or changed the context?

Statistical analysis cannot provide an in-depth understanding of the processes, but it offers a complementary overview that heretofore has been missing from this debate. Furthermore, this study aims to provide a clear distinction between Blair and Cook, as well as a testable measure of the salience of morality in relation to national interest in rhetoric. This will ensure a more nuanced view of morality's place in the agenda and will help distinguish a radical shift-in which morality is more important than national interest-from a moderate shift. The following hypotheses have been devised:

Hypothesis 1: Margaret Thatcher spoke less frequently about morality than national interest.

We will investigate whether the Conservatives were in fact less concerned with morality in their discourse than national interest. Moreover, our empirical analysis will show how big this difference between morality and national interest was. 
Hypothesis 2: Tony Blair and Robin Cook spoke equally frequently about morality.

We aim to reveal whether a difference exists between Blair's and Cook's emphases upon morality. Heretofore, the assumption in other research has been either to treat them interchangeably or to regard Cook's views as overarching. The assumption to be tested is that there is no significant difference between the two.

Hypothesis 3: Tony Blair and Robin Cook both spoke more frequently about morality than national interest.

Another point of interest regards the extent to which Blair and Cook broadened the rhetorical context of foreign policy. Did they raise morality to a moderate degree or were they radical in that morality took salience above national interest? Dunne and Wheeler $(2001,171)$ clearly define a GIC as one that puts the welfare of international society ahead of national interests, and supposedly Blair and Cook have done so in their discourse.

Hypothesis 4: Tony Blair spoke more frequently about morality than Margaret Thatcher.

Lastly, this study establishes the difference between the Conservatives and New Labour in the level of emphasis upon morality, and its extent. The current understanding is that the Conservative government was less concerned about morality in its foreign policy agenda than New Labour. In light of theoretical discourse claiming that New Labour significantly changed the rhetoric and thus the context of foreign policy, it is useful to establish empirically whether this position is supported and to what extent. What must be kept in mind is that such claims stem partly from the synonymous use of Blair and Cook as representatives of the New Labour foreign policy agenda. However, in the face of strong indications of tensions between the two, and for the sake of consistency with Thatcher as the representative for the Conservative position, this article will distinguish between Blair and Cook and use only Blair as the indicator for New Labour's foreign policy agenda. The next section will detail the chosen research design and process.

\section{Methodology}

This section will firstly explicate the advantages and pitfalls of the research design, then highlight considerations made during the research process and outline any problems encountered and steps taken to overcome these problems.

This study utilises a statistical approach to complement preceding research in the field, which is mainly qualitative in nature. It is based on secondary data such as newspaper articles, statements, speeches (auto)biographies and governmental documents. These are comprehensive, readily available via the Internet and authentic in the sense that they are official, and can be used to make general observations both over time and across actors. We used TEXTPACK (www.gesis.org) for this analysis. As Judith Bara $(2001,222)$ testifies in her study, 'it provides for construction of dedicated dictionaries, "key word in context" checks and interfaces with readily available statistical packages such as SPSS' (Bara 2001, 222). Most importantly TEXTPACK codes words, word roots and word strings. 
The discourse of choice is speeches; they represent a method employed by political leaders to set the agenda and persuade others. In a study of American presidential speeches, Lydia Andrade and Garry Young (1996, 592; see also Williamson 1999, 15) state that speeches 'provide the president with the best opportunity to influence the public because the president maintains complete control of the location, subject, and audience'. They also state that 'there is reason to believe that measuring speech content directly taps into the more general concept of the president's agenda'. Speeches are thus tools to present what the speaker and his or her party are offering, but also a means of laying down the range of possibilities. Speeches, however, cannot guarantee that subsequent behaviour will reflect the content. They are indicators rather than determinants of policy decisions taken later (Andrade and Young 1996, 591; Williamson 1999, 14). In this study, the intention is to assess New Labour's agenda in relation to that of the Conservatives, and to establish empirically whether or not and to what extent ethics featured in their discourse. The fact that speeches may not reflect subsequent policy choices therefore presents no methodological problem.

The use of computer software allowed us to use as many relevant documents as available. Criteria for speeches to be included in the sample were as follows: (a) the speech was held during the years in government; (b) the predominant part of the speech (i.e. more than half) was about foreign policy issues, defence, global issues or international and transnational organisations and corporations; (c) the speech qualified automatically if it was made within a foreign country; (d) the speech was not about the European Union (EU) or made to an EU governmental audience. ${ }^{1}$

Blair's speeches were gathered from the Number 10 Downing Street website (http://www.number-10.gov.uk/). As an official governmental website, the sampling frame held a high level of authenticity. The website represents the most comprehensive collection of readily available speeches and is thus considered the best reliable source. Overall, 68 of Blair's speeches matched the criteria described above and were considered for analysis.

Cook's speeches were collected from the Foreign and Commonwealth Office (FCO) website (http://www.fco.gov.uk/). Again, only those meeting the above criteria were included. ${ }^{2}$ In total, 37 speeches by Cook were included. The smaller number compared to Blair's can be attributed to the fact that Cook ended his term after only four years in power, six years before Blair left his premiership.

Thatcher's speeches were taken from the Thatcher Foundation website (http:// www.margaretthatcher.org/). A negligible number came in an unusable format (e.g. media broadcasts or original notes) and were therefore omitted. To ensure the speeches were suitable, only documents clearly labelled as 'Speech' or 'HCS' (Houses of Commons Speech) were considered. In the case of the latter, many were followed by a questions and answers section; these were omitted from the analysis. In total, 311 speeches by Thatcher were included in the final analysis.

To create the dictionaries, one text was selected to represent each politician's general views on foreign policy. For Blair, it was his 1999 'Doctrine of International Community' speech; for Cook it was the 1997 'FCO Mission Statement'; and for Thatcher, it was her 1989 'Speech to International Democrat Union Conference in 
Tokyo'. In order to achieve what Klaus Krippendorff $(1980,161)$ calls 'semantic validity', whereby the dictionary must be 'sensitive to the linguistic contexts of the word' as well as ensuring the correct meanings, we applied a three-step process. First, we assessed the three texts and picked out the words and phrases that represented either of the variables 'morality' or 'national interest'. This was done by selecting words and phrases that clearly matched the concepts identified in the literature, for example 'moral', 'environment', 'national interest' and 'sovereignty'. In a second step, sentences were identified that carried meanings of morality or national interest and the nouns, adjectives and phrases carrying those meanings were picked out. It became clear, for example, that words such as 'international' and 'United Nations' were consistently used in value-laden ways. This led to a dictionary of 189 words, word roots and word strings. ${ }^{3}$

In a third step, to ensure the validity of the finalised dictionary, we ensured that the entries predominantly carried the attributed meanings by checking all entries using the Key Word In Context (KWIC feature). Where necessary, the dictionary was adjusted. The 'National Interest' entry 'leadership' illustrates the process: the word was lifted from three sentences in Cook's FCO Mission Statement (emphasis added): (1) 'This cluster of opportunities for Britain to provide leadership will make the next year a uniquely exciting and rewarding period in foreign affairs'; (2) 'to make the United Kingdom a leading player in Europe'; and (3) 'It aims to make Britain a leading partner in a world community of nations, and reverses the Tory trend towards not so splendid isolation'. Applying the dictionary to another speaker's KWIC list, e.g. Blair's, the majority of uses of 'leadership', 'leading player' and 'leading partner' refer to British regional or world leadership. There are some anomalies, for example with reference to 'African leadership' or 'under the leadership of HM King Abdullah', as well as more general phrases such as 'lesson of leadership', but such anomalies are to be expected and their number for this dictionary entry was deemed acceptable.

In conclusion, we applied computer-assisted content analysis to facilitate a reliable, highly replicable and efficient measurement of the levels of morality in the Conservative and New Labour foreign policy speeches. TEXTPACK software and common statistical software were used for analyses. The coding and sampling processes, nonetheless, required an element of researcher interpretation in order to maintain validity.

\section{Results and Findings}

The results of the analysis point towards a significant difference in the salience of ethical standards between Thatcher's and Blair's rhetoric. The results support Wheeler and Dunne's assumptions, although they do come with important caveats.

Due to the differences in numbers and lengths of speeches, rates of the variables were compared rather than sums. Rates were calculated by sentence. For example, the rate of 'morality codes' for Blair in 1997 was discovered by dividing the total number of codes occurring in that year's speeches by the total number of sentences spoken in that year. The rate of the codes also represents the relative importance of the corresponding variable; thus, the higher the rate, the more important the variable. 
Figure 1: Margaret Thatcher

\section{Average Rate of Morality and National Interest Per Year}

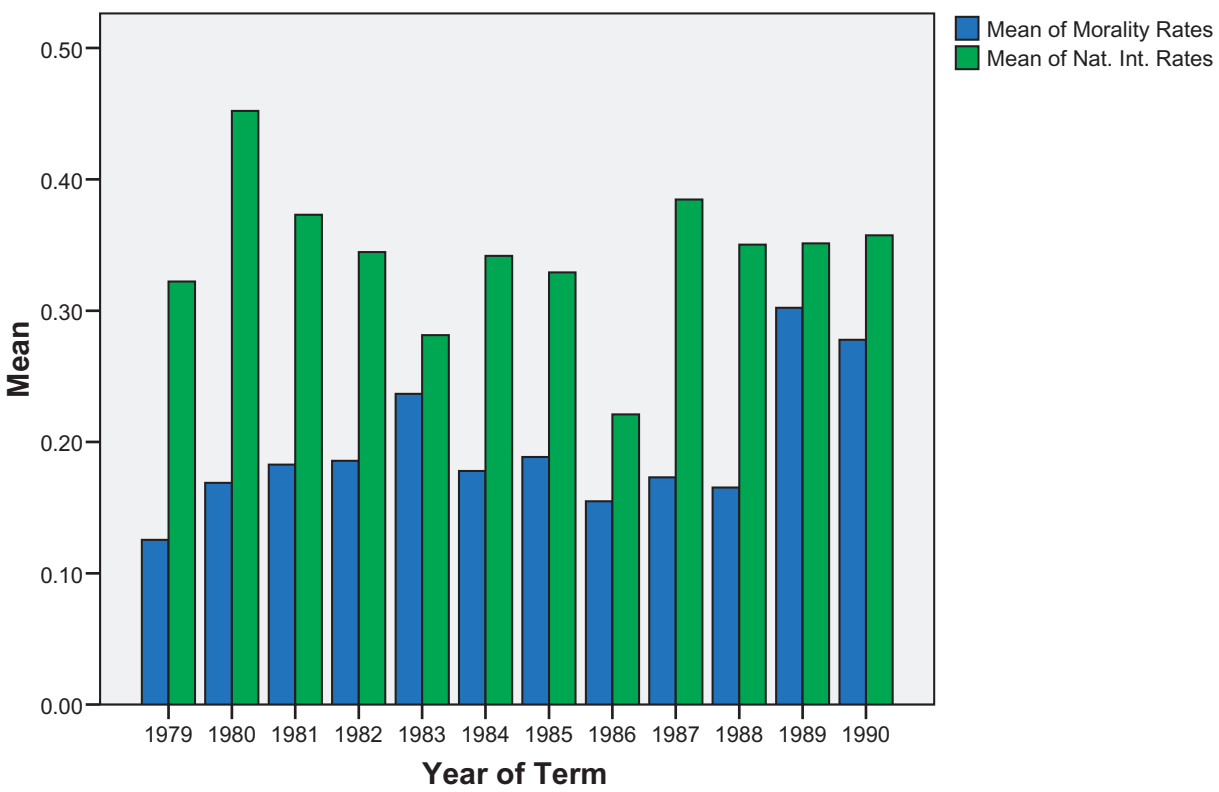

Figure 1 shows that the mean rate of morality for Thatcher's entire term is 0.20 , while the mean rate of national interest is 0.33 . This means that she spoke a morality code every fifth sentence and a national interest code every third sentence; national interest codes were thus spoken over 50 per cent more than morality codes. Thatcher used moral language less than language regarding British national interests. The rate for both topics remained relatively constant across all years. In no year did she speak on average more about morality than national interest.

Figure 2 presents the results for Blair. Overall, the mean rate of morality in his speech was 0.33, while the rate of national interest was 0.41. The difference between morality and national interest is not as great as with Thatcher, with national interest being spoken roughly a third more than morality.

As indicated before, there are caveats to these findings. Firstly, while Blair spoke on average more frequently about morality than Thatcher, he also spoke more frequently about national interest than Thatcher. Thatcher's national interest rate never rose above 0.45 while Blair's rose three times to 0.50 or higher. Second, Blair's rate pattern displays a switch in discourse over time. For the first five years in government (1997-2001), a sizeable gap exists between the rates of morality and national interest. The average rates for this time period are 0.25 for morality and 0.51 for national interest. In the final six years (2002-07), the rates reversed and morality was spoken of more frequently than national interest in two thirds of the years. On average, morality codes rose to 0.40 while national interest dropped to 0.32. This change coincides with the events of $9 / 11$. Thus, broken down to a first 


\section{Figure 2: Tony Blair}

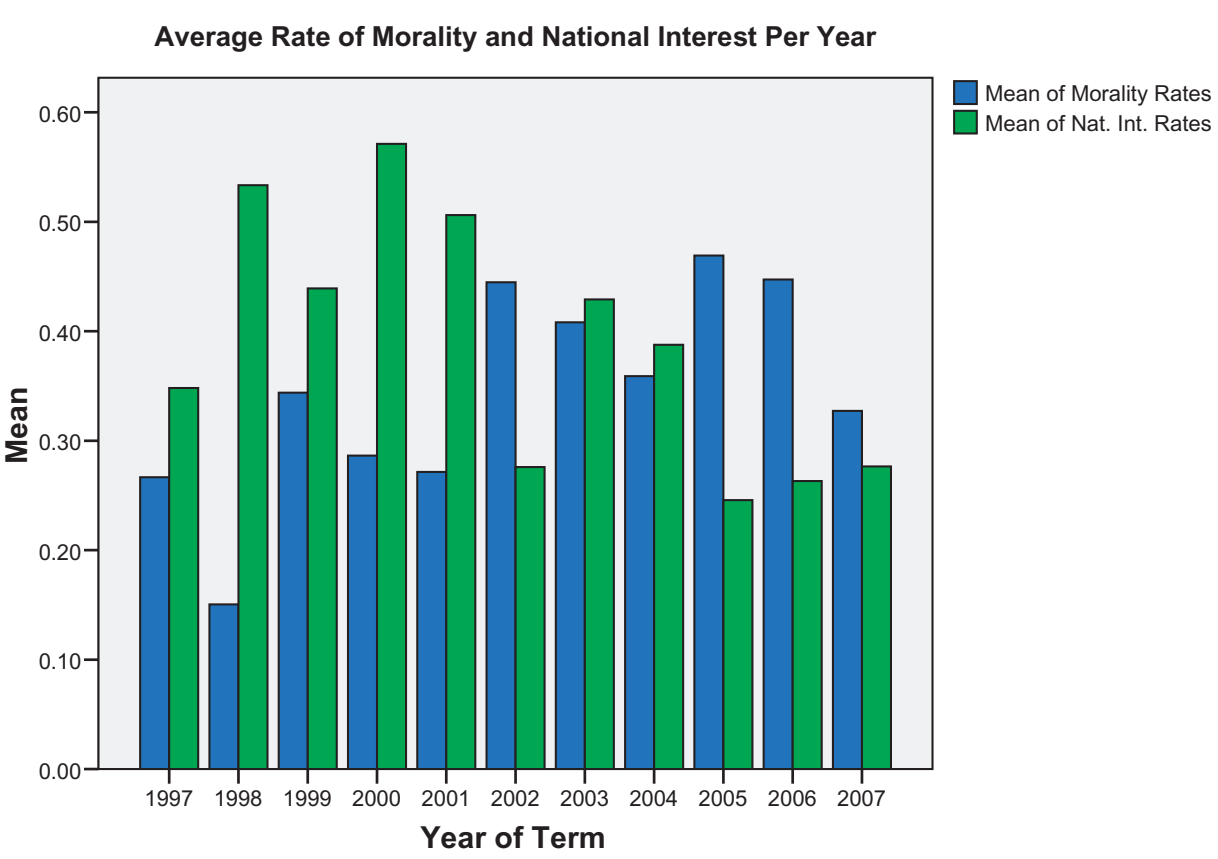

and a second New Labour period, the former showed no remarkable difference to the Conservatives' foreign policy agenda.

Figure 3 shows Cook's speeches. Of all three speakers, he uses moral language most frequently. In nearly all years, the rate of morality remained higher than that of national interest. The difference was greatest in 1997, when morality was spoken of almost twice as frequently as national interest. Only in 1998 did national interest score higher than morality.

These findings represent a stark difference between Blair's and Cook's emphases in foreign policy discourse. When comparing the rates for 1997-2001, Cook spoke consistently more about morality than Blair. Upon averaging the rates, he talked nearly twice as much about morality as Blair while speaking a fifth less about national interest.

The following links the results to the hypotheses. It will also explore anomalies in Blair's moral rhetoric and indicate implications for other studies in the field.

Hypothesis 1 stated that Thatcher spoke less frequently about morality than national interest. This hypothesis is borne out. Referring to Figure 1, in no year did Thatcher use moral language more than national interest language. Only in the final two years of her last term in government did morality notably rise in relation to national interest, which remained relatively stable. This finding supports previous theoretical studies that were based on the premise that the Conservative government was not particularly concerned about ethics in its foreign policy agenda. 


\section{Figure 3: Robin Cook}

\section{Average Rate of Morality and National Interest Per Year}

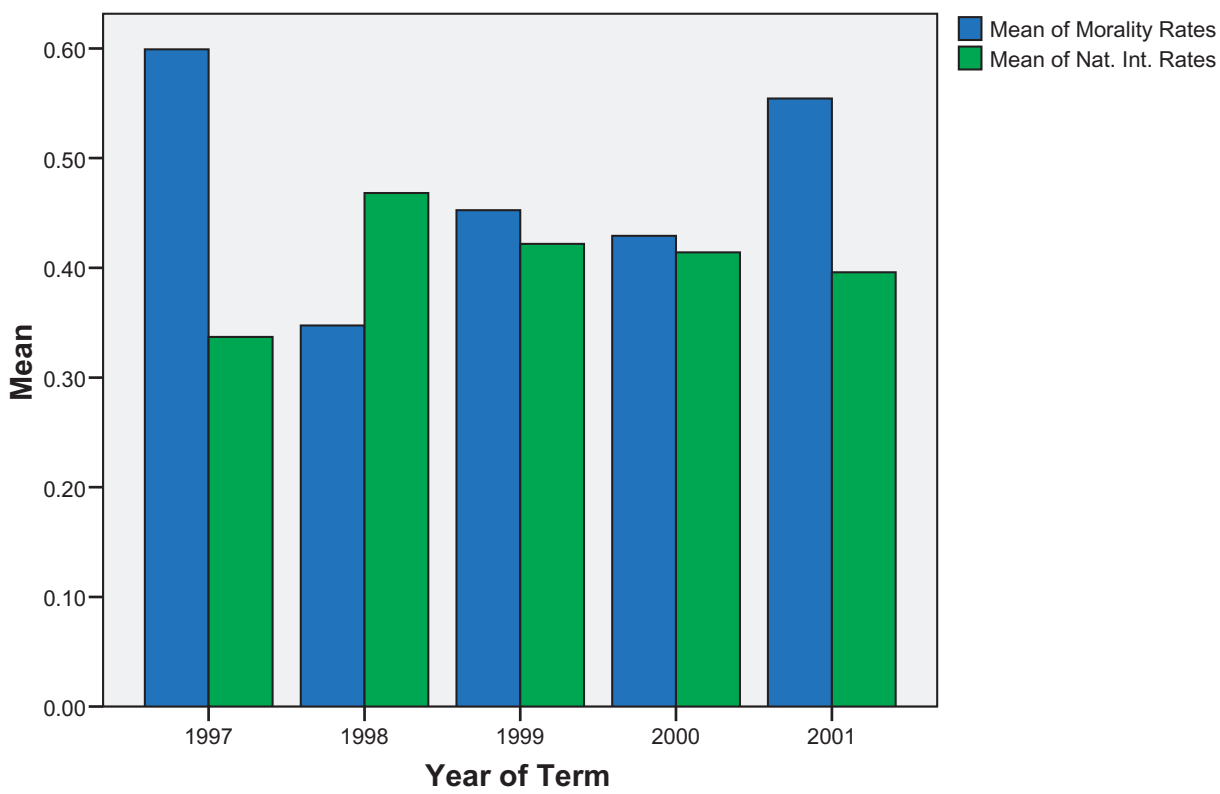

Hypothesis 2 affirmed that Blair and Cook spoke equally frequently about morality. It establishes the congruence of their emphases upon ethics in foreign policy. Figures 2 and 3, however, show no instance of convergence in rhetoric between 1997 and 2001, the years Blair and Cook shared in government. Blair's highest morality rate was 0.34, while this was actually Cook's lowest (range 0.34-0.59). Blair spoke of morality at an average rate only 0.05 more than Thatcher while Cook spoke more than twice as much about morality as Thatcher. This indicates that the two, although more committed to ethics in their foreign policy agendas than Thatcher, were nonetheless committed to varying degrees. Cook's stance was more radical with a stronger emphasis on morality than on national interest, while Blair remained in favour of national interest.

This finding clearly shows that Blair and Cook did not share an outlook on the prominence of morality while being in government together. This weighs against the interchangeable use of Blair and Cook in studies such as Bartlett's (2000) to indicate the rhetorical context.

Hypothesis 3 stated that Blair and Cook both spoke more frequently about morality than national interest. Its purpose was to establish the extent to which they both diverged from the Conservative precedent. We distinguish between a moderate change, in which national interest remains more salient than morality, and a radical change, in which morality becomes more prominent than national interest. Figures 2 and 3 confirm Blair's moderate and Cook's radical approach. Looking at the averages for the five shared years, Blair held national interest to be twice as 
Table 1: Tony Blair: Number and Rates of Codes for Speeches 2001-02

\begin{tabular}{|c|c|c|}
\hline Speech & $\begin{array}{l}\text { Rate of } \\
\text { morality }\end{array}$ & $\begin{array}{l}\text { Rate of } \\
\text { national } \\
\text { interest }\end{array}$ \\
\hline January 2001 'Speech on the Holocaust' & 0.37 & 0.13 \\
\hline $\begin{array}{l}\text { February } 2001 \text { 'Prime Minister Tony Blair's Speech to the } \\
\text { Canadian Parliament' }\end{array}$ & 0.16 & 0.62 \\
\hline $\begin{array}{l}\text { March } 2001 \text { 'Speech by the Prime Minister: "Environment: } \\
\text { The Next Steps"' }\end{array}$ & 0.46 & 0.34 \\
\hline July 2001 ‘Prime Minister's Speech in Sao Paolo, Brazil’ & 0.14 & 0.72 \\
\hline Total & 0.27 & 0.50 \\
\hline February 2002 'Speech to Ghana's Parliament' & 0.60 & 0.21 \\
\hline $\begin{array}{l}\text { April } 2002 \text { 'Prime Minister's Speech at the George Bush Senior } \\
\text { Presidential Library' }\end{array}$ & 0.40 & 0.32 \\
\hline $\begin{array}{l}\text { September } 2002 \text { 'Prime Minister's Speech to the WSSD in South } \\
\text { Africa' }\end{array}$ & 0.46 & 0.15 \\
\hline $\begin{array}{l}\text { September } 2002 \text { 'Prime Minister's Speech to TUC Conference in } \\
\text { Blackpool' }\end{array}$ & 0.42 & 0.19 \\
\hline December 2002 'PM's New Year Address to the Falkland Islands' & 0.40 & 0.70 \\
\hline Total & 0.44 & 0.27 \\
\hline
\end{tabular}

important as morality while Cook held morality to be more important than national interest. Even when including the latter years of Blair's premiership, his average morality rate is roughly a quarter less than national interest.

This confirms again that our approach to question the congruence of the two politicians was correct. Future research should pay more attention to this distinction and the decision for choosing either of them should be thoroughly justified.

Hypothesis 4 stated that Blair spoke more frequently about morality than Thatcher. Having taken the position that Blair rather than Cook represented New Labour's foreign policy agenda while Thatcher represented that of the Conservatives, the purpose of this hypothesis was to establish whether New Labour's foreign policy agenda truly was more ethical than that of the Conservatives. Our findings bear out assumptions that this was the case and that Blair did indeed speak more frequently about morality than Thatcher. This change was, however, only radical in the latter half of his years in power. Until the end of 2001, Blair's discourse indicates a negligible inclusion of moral rhetoric. Only from 2002 did ethics take centre stage in foreign policy. Table 1 presents the details for four 2001 and five 2002 speeches to show this pattern. Instances in which morality appeared at a higher rate than national interest are in bold.

As mentioned earlier, this changing pattern coincides with the terrorist attack upon the World Trade Centre on 11 September 2001. A link between these two events appears likely for a number of reasons. Firstly, Blair is understood by some as having used moral language to help raise his flagging status in the polls (Seldon 
2004, 499; also BBC 2007b for poll results over time). Secondly, the events of 9/1 1 struck true with his conception of Britain's place in the world and boosted his confidence in the place of ethics in international relations. According to Anthony Seldon $(2004,511)$, 'the events of $9 / 11$ changed Blair profoundly and deepened his sense of the moral futility of being a powerful nation but not acting in the face of grave wrongs'. For Blair, the world had become a new place in which pacifism held no place and global injustices had to be addressed. Moreover, 9/11 reinforced his view of internationalism being the answer to meeting grave threats; terrorism and the proliferation of nuclear weapons could never be dealt with unilaterally, and this was a good chance to re-emphasise that message. Thirdly, and perhaps most importantly, for it clarifies a change in conception, Blair may not have truly understood until his second term what he wanted his legacy to be (Seldon 2005, 415416) and his language became an explicit account of tendencies that had lurked until then underused and under-emphasised. As Philip Stephens states:

The prime minister who returned to Downing Street in June 2001 understood the challenges facing him. He came to the task a different politician. His first term of office had often seemed a series of separate, albeit virtuoso, performances, played for the next morning's reviews. The second saw a prime minister with his eye on the history books (Stephens 2004, 175).

Seldon (2004, 695; see also BBC 2007a) claims that 'he [Blair] reconciled himself to delaying the fulfilment of his still inchoate personal agenda until after the 2001 election' because he wanted to avoid controversial and radical decisions in order to maintain powerful business and media support. An important part of that legacy was to be the establishment of a more humanitarian foreign policy towards Africa and the Middle East, a focus upon the environment, the strengthening of internationalist principles and thus a strengthening of Britain's role in the world. It is remarkable that Blair did not inherently became a more moral man, but that 9/11 affected the moral traits and values already inherent in him and led him to emphasise them more strongly in his rhetoric. The mid-point between the pre-9/11 New Labour and the post-9/11 New Labour thus represents a shift from a traditional foreign policy agenda to a more ethics-oriented one.

These findings have implications for existing and future studies in the field. Any claim of New Labour being more ethical than the Conservatives needs to be mindful of the specific period. Wheeler and Dunne's (1998; Dunne and Wheeler 2001) proposal of a GIC and a stronger role for ethics based on New Labour rhetoric represents an instance of jumping the gun. Robin Cook may have been ready to introduce ethics in a prominent role, but the leader of the party, Tony Blair, was not.

Summing up, New Labour did indeed shift the rhetorical context of foreign policy by incorporating an ethical dimension. However, ethics did not make it on to Blair's agenda in a meaningful sense until after 2001. Beforehand, only Cook marked a radical difference. Blair only took a radical stance in the final few years of his premiership, when his emphasis upon national interest dropped compared to ethics. 


\section{Conclusion}

This study aimed to map the salience of moral language in rhetoric in order to test the assumption that New Labour's ascendance to government represented a shift in the context of foreign policy. We did this by using a quantitative methodology heretofore not applied to this topic area in order to complement existing qualitative studies. This method provided a wider view of New Labour's rhetoric and enabled us to state the measurable degree of change from Conservatives to New Labour. This approach proved successful in that it reinforced that New Labour under Blair did adopt a more moral rhetoric — and thus a more moral foreign policy agendathan the previous Conservative governments. It added to the discussion by revealing that this shift was not eminent until 2002 and suggests that it was due to the events of September 11 th. Lastly, this study highlights the importance of distinguishing between Blair and Cook when assessing New Labour rhetoric, or at least thoroughly justifying the decision if assessing these two interchangeably.

One limitation of this study is its sole focus on Thatcher's rhetoric to indicate the Conservative foreign policy agenda. Ignoring John Major's time in government leaves a seven-year gap; however, this choice was justified by the consideration that Thatcher was the more important agenda setter for the Conservatives.

Some more general implications can be drawn from this study which might stimulate future research. Firstly and most importantly, it highlights the fundamental importance of 9/11 in affecting New Labour's foreign policy agenda. Although Blair did in himself have a moral dimension, his political agenda was restricted to issues of national interest by his need to win the popular vote and his lack of a conception for his own political legacy. After $9 / 11$, he became more vocal about ethics in foreign policy, indicating a growing confidence in making this issue more central. It might in this respect be useful to study what other impacts 9/1 1 may have had upon British political discourse.

Evidence of this study also points to discrepancies between foreign secretaries' and prime ministers' rhetoric and how this affects the ways in which the party as a whole is perceived. In the first five years in government, Blair and Cook held diverging positions on the prominence of ethics in British foreign policy, which ultimately impacted upon the judgement of New Labour's actions. For example, according to Cook's level of emphases upon ethics, New Labour's actions fell far short of the standard (Bartlett 2000; Miller 2000; Abrahamsen and Williams 2001); however, when judged in view of Blair's initial continuity with the Conservatives' agenda, they did not.

Finally, future research could investigate whether the trend of an ethical dimension in British foreign policy has continued. With a change in leadership to Gordon Brown in 2007, new foreign policy trends might be expected. Brown's foreign policy speech at the John F. Kennedy memorial library in April 2008 was described as 'his answer to Tony Blair's landmark 1999 Chicago speech' (The Guardian, 19 April 2008) and questions have arisen as to whether he will change the course of British foreign policy (BBC 2007c). Furthermore, the suggestion that New Labour changed the context of foreign policy might lead to the expectation of an impact 
upon the rhetoric of newer generations of opposition party leaders such as David Cameron. Cameron has already been likened to Blair (The Independent, 5 December 2005; Workers Power 2006), and the question is whether the trend of more ethics in foreign policy discourse is fleeting or not.

\section{About the Authors}

Densua Mumford, School of Politics and International Relations, University of Nottingham, University Park, Nottingham NG7 2RD, UK, email: d-mumford@hotmail.co.uk

Torsten J. Selck, Department of Political Science, Bilkent University, 06800 Bilkent, Ankara, Turkey, email: selck@bilkent.edu.tr

\section{Notes}

We are indebted to Steven Fielding, Will Lowe and Constanze Kathan for their invaluable comments and suggestions.

1. The last criterion was deliberately chosen to prevent irrelevant data from distorting the results as it became clear that the EU, while a foreign policy issue, would be highly unlikely to reflect 'morality'.

2. The FCO website produced blank documents for two seemingly relevant speeches: 'Foreign Policy and National Interest' (January 2000) and 'Remembering the Holocaust; Looking to the Future' (January 2000). These two speeches were therefore omitted.

3. The codebook used for this article is available upon request by emailing to the first author.

\section{Bibliography}

Abrahamsen, R. and Williams, P. (2001) 'Ethics and foreign policy: The antinomies of New Labour's “Third Way" in sub-Saharan Africa', Political Studies, 49:2, 249-264.

Andrade, L. and Young, G. (1996) 'Presidential agenda setting: Influences on the emphasis of foreign policy', Political Research Quarterly, 49:3, 591-605.

Bara, J. (2001) 'Tracking estimates of public opinion and party policy intentions in Britain and the USA', in M. Laver (ed.), Estimating the Policy Position of Political Actors (London: Routledge), 217-236.

Bartlett, W. (2000) "'Simply the right thing to do": Labour goes to war', in R. Little and M. Wickham-Jones (eds), New Labour's Foreign Policy: A New Moral Crusade? (Manchester: Manchester University Press), 131-146.

BBC (2007a) 'How will history judge Blair?', 10 May. Available online at: http://news.bbc.co.uk/1/hi/ uk_politics/6636091.stm (accessed 19 April 2008).

BBC (2007b) 'Tony Blair: Highs and lows', 10 May. Available online at: http://news.bbc.co.uk/1/hi/ uk_politics/4717504.stm (accessed 19 April 2008).

BBC (2007c) 'Will Brown change UK foreign policy?' 28 June. Available online at: http://news.bbc.co.uk/ 1/hi/uk_politics/6234592.stm (accessed 19 April 2008).

Beitz, C. (1975) 'Justice and international relations', Philosophy and Public Affairs, 4:4, 360-389.

Beitz, C. (1999) 'Social and cosmopolitan liberalism', International Affairs, 75:3, 515-529.

Bogdanor, V. (2005) 'Commentary: Foreign policy', in A. Seldon and D. Kavanagh (eds), The Blair Effect 2001-5 (Cambridge: Cambridge University Press), 445-452.

Buller, J. and Harrison, V. (2000) 'New Labour as a "good international citizen": Normative theory and UK foreign policy', in R. Little and M. Wickham-Jones (eds), New Labour's Foreign Policy: A New Moral Crusade? (Manchester: Manchester University Press), 77-89.

Campbell, J. (2003) Margaret Thatcher Volume Two: The Iron Lady (London: Jonathan Cape).

Campbell, J. (2009) Margaret Thatcher Grocer's Daughter to Iron Lady (London: Vintage). 
Cooper, N. (2000) 'The pariah agenda and New Labour's ethical arms sales policy', in R. Little and M. Wickham-Jones (eds), New Labour's Foreign Policy: A New Moral Crusade? (Manchester: Manchester University Press), 147-167.

Cradock, P. (1997) In Pursuit of British Interests (London: John Murray).

Dixon, R. and Williams, P. (2001) 'Tough on debt, tough on the causes of debt? New Labour's Third Way foreign policy', British Journal of Politics ef International Relations, 3:2, 150-172.

Dunne, T. and Wheeler, N. J. (2001) 'Blair's Britain: A force for good in the world?', in K. E. Smith and M. Light (eds), Ethics and Foreign Policy (Cambridge: Cambridge University Press), 167-184.

Fierke, K. M. (2001) 'Constructing an ethical foreign policy: Analysis and practice from below', in K. E. Smith and M. Light (eds), Ethics and Foreign Policy (Cambridge: Cambridge University Press), 129-144.

Greene, O. (2005) 'Environmental issues', in J. Baylis and S. Smith (eds), The Globalization of World Politics: An Introduction to International Relations (Oxford: Oxford University Press), 451-478.

Held, D. and McGrew, A. (2002) Globalization/Anti-Globalization (Malden, MA: Polity Press).

Hennessy, P. (2001) The Prime Minister: The Office and Its Holders Since 1945 (London: Penguin Books).

Hill, C. (2005) 'Putting the world to rights: Tony Blair's foreign policy mission', in A. Seldon and D. Kavanagh (eds), The Blair Effect 2001-5 (Cambridge: Cambridge University Press), 384-409.

Kampfner, J. (1999) Robin Cook: The Life and Times of Tony Blair's Most Awkward Minister (London: Phoenix).

Krippendorff, K. (1980) Content Analysis: An Introduction to its Methodology (London: SAGE).

Little, R. (2000) 'Conclusions: The ethics and the strategy of Labour's Third Way in foreign policy', in R. Little and M. Wickham-Jones (eds), New Labour's Foreign Policy: A New Moral Crusade? (Manchester: Manchester University Press), 251-263.

Marr, A. (2008) A History of Modern Britain (London: Pan Books).

Miller, D. (2000) 'British foreign policy, human rights and Iran', in R. Little and M. Wickham-Jones (eds), New Labour's Foreign Policy: A New Moral Crusade? (Manchester: Manchester University Press), 186-200.

Perraton, J., Goldblatt, D., Held, D. and McGrew, A. (2000) 'Economic activity in a globalizing world', in D. Held and A. McGrew (eds), The Global Transformations Reader (Cambridge: Polity Press), 287-300.

Porteous, T. (2005) 'British government policy in sub-Saharan Africa under New Labour', International Affairs, 81:2, 281-297.

Riddell, P. (1991) The Thatcher Era (Oxford: Blackwell).

Robins, K. (2000) 'Encountering globalization', in D. Held and A. McGrew (eds), The Global Transformations Reader (Cambridge: Polity Press), 195-201.

Seldon, A. (2004) Blair (London: The Free Press).

Seldon, A. (2005) 'The second Blair government: The verdict', in A. Seldon and D. Kavanagh (eds), The Blair Effect 2001-5 (Cambridge: Cambridge University Press), 410-429.

Seldon, A. and Snowdon, P. (2004) The Conservative Party: An Illustrated History (Stroud: Sutton Publishing).

Stephens, P. (2004) Tony Blair: The Making of a World Leader (New York, London: Viking).

Strange, S. (2000) 'The declining authority of states', in D. Held and A. McGrew (eds), The Global Transformations Reader (Cambridge: Polity Press), 148-155.

UNDP (2000) 'Globalization with a human face', UNDP Report 1999, in D. Held and A. McGrew (eds), The Global Transformations Reader (Cambridge: Polity Press), 341-347.

Vickers, R. (2000) 'Labour's search for a Third Way in foreign policy', in R. Little and M. Wickham-Jones (eds), New Labour's Foreign Policy: A New Moral Crusade? (Manchester: Manchester University Press), 33-48.

Wheeler, N. J. and Dunne, T. (1998) 'Good international citizenship: A Third Way for British foreign policy', International Affairs, 74:4, 847-870.

Wheeler, N. J. and Dunne, T. (2004) 'Moral Britannia? Evaluating the ethical dimension of Labour's foreign policy', Foreign Policy Centre Report. Available online at: http://fpc.org.uk/publications/121.

Wickham-Jones, M. (2000a) 'Labour's trajectory in foreign affairs: The moral crusade of a pivotal power?', in R. Little and M. Wickham-Jones (eds), New Labour's Foreign Policy: A New Moral Crusade? (Manchester: Manchester University Press), 3-32.

Wickham-Jones, M. (2000b) 'Labour party politics and foreign policy', in R. Little and M. Wickham-Jones (eds), New Labour's Foreign Policy: A New Moral Crusade? (Manchester: Manchester University Press), 93-111. 
Williamson, P. (1999) Stanley Baldwin: Conservative Leadership and National Values (Cambridge: Cambridge University Press).

Workers Power (2006) 'David Cameron: The Tories' own Blair', 16 January. Available online at: http:// www.workerspower.com/index.php?id=47,911,0,0,1,0 (accessed 1 May 2008). 